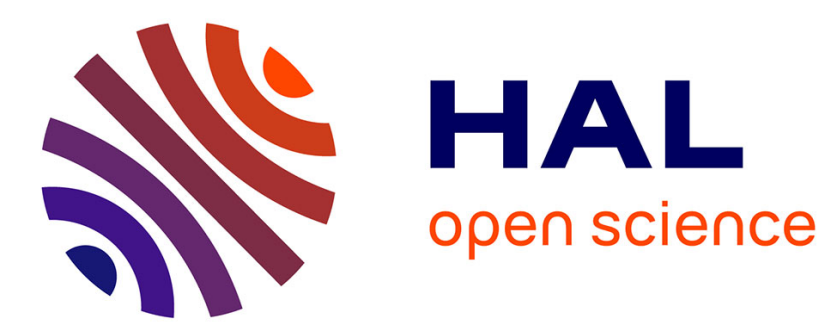

\title{
Effect of Gold on the Nickel/Silicon Thin Film Reaction
} Dominique Mangelinck, P. Gas, J. Gay, B. Pichaud

\section{To cite this version:}

Dominique Mangelinck, P. Gas, J. Gay, B. Pichaud. Effect of Gold on the Nickel/Silicon Thin Film Reaction. Journal de Physique IV Proceedings, 1996, 06 (C2), pp.C2-97-C2-102. 10.1051/jp4:1996213 . jpa-00254191

\section{HAL Id: jpa-00254191 https://hal.science/jpa-00254191}

Submitted on 1 Jan 1996

HAL is a multi-disciplinary open access archive for the deposit and dissemination of scientific research documents, whether they are published or not. The documents may come from teaching and research institutions in France or abroad, or from public or private research centers.
L'archive ouverte pluridisciplinaire HAL, est destinée au dépôt et à la diffusion de documents scientifiques de niveau recherche, publiés ou non, émanant des établissements d'enseignement et de recherche français ou étrangers, des laboratoires publics ou privés. 


\title{
Effect of Gold on the Nickel/Silicon Thin Film Reaction
}

\author{
D. Mangelinck, P. Gas*, J.M. Gay** and B. Pichaud \\ Laboratoire MATOP, associé au CNRS, Case 151, Faculté des Sciences de Saint Jérôme, \\ 13397 Marseille cedex 20, France \\ * Laboratoire de Métallurgie, associé au CNRS, Case 522, Faculté des Sciences de Saint Jérôme, \\ 13397 Marseille cedex 20, France \\ ** CRMC2-CNRS, Campus de Luminy, Case 913, 13288 Marseille cedex 9, France
}

\begin{abstract}
The solid state reaction between a nickel thin film and a silicon substrate leads to the sequential formation of $\mathrm{Ni}_{2} \mathrm{Si}$, $\mathrm{NiSi}$ and $\mathrm{NiSi}_{2}$. The growth of the two first silicides occurs at low temperature $\left(200-300^{\circ} \mathrm{C}\right)$ and is controlled by nickel diffusion. $\mathrm{NiSi}_{2}$ is only formed in a brutal manner at high temperature which indicates a nucleation controlled formation. We show that the addition of gold to the nickel film drastically affects these characteristics: Ni2 $\mathrm{Si}$ and $\mathrm{NiSi}$ appear simultaneously and the nucleation temperature of $\mathrm{NiSi}_{2}$ is lowered. The solubility of gold in the three silicides is limited which induces a precipitation of gold. Depending on temperature this precipitation takes various forms: gold enriched surface layer or gold clusters at inner interfaces.
\end{abstract}

\section{INTRODUCTION}

Reaction between thin-films of metallic alloys and silicon have been intensively investigated to analyze the mechanisms of silicide formation, to improve the metallurgical properties of silicide films (resistivity, stability), to achieve reliable contacts on shallow junctions or to tune the Schottky barrier height. In most cases the metal added is a silicide forming metal (e.g. Co [1] or Pt [2]). The case of alloys where one of the metals does not form silicides (e.g. Au) has been much less studied.

In this paper we present the results of an investigation of the effect of a gold addition on the formation of nickel silicides. Let us remind that there is no stable compounds between $\mathrm{Au}$ and $\mathrm{Si}$ and that the solubilities are limited; quite the contrary the Au- Ni system is characterized by a complete solid solution at high temperatures and a appreciable solubility of both elements at lower temperatures [3]. We compare the different stages of the solid state reaction between a $\mathrm{Ni}(7 \mathrm{at} . \% \mathrm{Au}$ ) film and a (111) Si substrate to the equivalent stages observed in nickel - silicon reactions. A potential application is the modification of the lattice misfit in the $\mathrm{NiSi}_{2}(111) / \mathrm{Si}(111)$ heteroepitaxy by substitution of nickel by gold [4].

\section{EXPERIMENTAL PROCEDURE}

Films, about $50 \mathrm{~nm}$ thick were deposited via vacuum evaporation from an electron beam heated source onto silicon (111) wafers. Prior to evaporation the wafers were degreased and cleaned by chemical etch in an $\mathrm{HF}$ $(1 / 10)$ solution. During the deposition the pressure was kept in the $10^{-7}$ Torr range, the rate of evaporation was about $0.1 \mathrm{~nm} / \mathrm{s}$ and the thickness of the metal film was measured with a quartz balance. Two different evaporation sources have been used: pure $\mathrm{Ni}$ and a $\mathrm{Ni}(1,5$ at.\% $\mathrm{Au})$ solid solution prepared from high purity $\mathrm{Ni}(5 \mathrm{~N})$ and $\mathrm{Au}(6 \mathrm{~N})$ [5]. Because of the different vapor pressures of $\mathrm{Au}$ and $\mathrm{Ni}$, the gold amount in the deposited film is equal to 7 at.\%. Pure nickel and $\mathrm{Ni}(7 \mathrm{at} \% \mathrm{Au})$ films were then annealed together in vacuum $\left(10^{-7}\right.$ Torr) at temperatures ranging from $250^{\circ} \mathrm{C}$ to $800^{\circ} \mathrm{C}$ and for time included between 30 minutes and 18 hours.

As deposited and annealed samples were analyzed by backscattering of ${ }^{4} \mathrm{He}^{+}$ions and by X-ray diffraction using a diffractometer with the Bragg-Brentano geometry, equipped with a copper anode. The samples morphology was observed by scanning electron microscopy associated with an energy dispersive spectrometry system.

\section{RESULTS}

The thicknesses and compositions of the different films were obtained by comparison of backscattering spectra and simulations based on the program RUMP [6]. The thickness of the as deposited nickel film was $50 \mathrm{~nm}$ while the $\mathrm{Ni}(7 \mathrm{at} . \% \mathrm{Au}$ ) was $41 \mathrm{~nm}$ thick. X-ray diffraction measurements of the lattice parameters in the as deposited films gave a linear evolution with gold content corresponding to the Vegard's law. This 
was confirmed by the linear variation of the films resistivity (deduced from the thicknesses and sheet resistance measurements) with gold concentration. Since the gold solubility in nickel decreases very rapidly with temperature [3], these layers are out of equilibrium at temperatures lower than $650^{\circ} \mathrm{C}$.

Figure 1 shows the backscattering spectra of pure $\mathrm{Ni}$ and $\mathrm{Ni}(\mathrm{Au})$ films, as deposited and annealed for 1 hour at temperatures ranging from $250^{\circ} \mathrm{C}$ to $800^{\circ} \mathrm{C}$.

After annealing at $250^{\circ} \mathrm{C}$ (Figure 1.b), a part of the pure nickel film has reacted with silicon to form $350 \mathrm{~nm}$ of $\mathrm{Ni}_{2} \mathrm{Si}$. The $\mathrm{Ni}(7 \mathrm{at} . \% \mathrm{Au})$ film has also reacted but the composition of the silicide is apparently between $\mathrm{Ni}_{2} \mathrm{Si}$ and $\mathrm{NiSi}$ (the silicide thickness is very small and the exact composition is difficult to precise). Gold is mainly kept in the unreacted nickel and its distribution is apparently non uniform; the maximum gold concentration if found at the silicide/unreacted layer interface. X-ray diffraction experiments showed diffraction lines belonging to $\mathrm{Ni}_{2} \mathrm{Si}$ and $\mathrm{NiSi}$ together with extra peaks corresponding to the $\mathrm{Ni}(\mathrm{Au})$ and $\mathrm{Au}(\mathrm{Ni})$ solid solutions. The backscattering spectra and the $\mathrm{X}$ ray diffraction results are thus in agreement and show the simultaneous presence of the unreacted metal and two silicides $\left(\mathrm{Ni}_{2} \mathrm{Si}\right.$ and $\left.\mathrm{NiSi}\right)$. Such a simultaneous formation is only observed in special cases (presence of impurities or reaction with amorphous silicon) during nickel silicides formation. In order to precise the mechanisms of this process, three samples have been annealed at $250^{\circ} \mathrm{C}$ for different times $(0.5 \mathrm{~h}, 1 \mathrm{~h}$ and $18 \mathrm{~h}$ ). RBS (Rutherford Back Scattering Spectrometry) spectra of these three samples showed that: i) a metal film remains at the free surface whatever the annealing time is; this film is progressively enriched in gold particularly at the silicide/metal interface, ii) a silicide is formed, its composition is difficult to determine because of it low thickness. Since the accuracy of backscattering spectra does not allow a precise determination of the silicide thickness, we have plotted in Figure 2, the thickness of the unreacted Ni(Au) layer (obtained from both gold and nickel RBS signals) versus the square root of annealing time. This figure shows that the rate of formation decreases with increasing time. A comparison with nickel consumption in pure nickel film shows that the initial growth rate is similar to the growth rate measured by Olowolafe et al [7] for $\mathrm{Ni}_{2} \mathrm{Si}$ growth on (111)Si. The details of silicide formation have been confirmed by X-ray diffraction: we have observed that the intensities of the $\mathrm{Ni}_{2} \mathrm{Si}$ peaks decrease with annealing time and the NiSi ones increase (for the sample annealed for 18 hours, $\mathrm{X}$ ray diffraction spectrum showed $\mathrm{NiSi}$ peak but no $\mathrm{Ni}_{2} \mathrm{Si}$ peaks). The formation of $\mathrm{NiSi}$ and $\mathrm{Ni}_{2} \mathrm{Si}$ is thus simultaneous and for long annealing times NiSi grow at the expense of both $\mathrm{Ni}_{2} \mathrm{Si}$ and $\mathrm{Ni}$.

After annealing at $300^{\circ} \mathrm{C}$ (for one hour) the pure nickel film has been consumed to form a $\mathrm{Ni}_{2} \mathrm{Si}$ layer (45 $\mathrm{nm}$ thick) on top of a NiSi layer ( $45 \mathrm{~nm}$ thick). The same silicides are observed in the gold containing film but the NiSi layer is much thinner and unreacted metal (mainly gold) remains. The gold signal can be divided in three parts (Figure 1.h). The peak at $\mathrm{E}=1.67 \mathrm{MeV}$ corresponds to "surface" gold and may be simulated as a $0.8 \mathrm{~nm}$ thick gold layer located at the surface. Between 1.65 and $1.60 \mathrm{MeV}$ the signal of low intensity corresponds to the concentration of gold dissolved in $\mathrm{Ni}_{2} \mathrm{Si}$ (about 0.1 at.\%). The last component of the gold signal $(1.6 \mathrm{MeV}>\mathrm{E}>1.4 \mathrm{MeV})$ could be interpreted as a gold diffusion in silicon. Although the gold solubility limit at $300^{\circ} \mathrm{C}$ in silicon is not known, the very low solubility of this metal at high temperature [4] implies that this is not a realistic interpretation. In fact this signal is due to the presence of gold clusters. These clusters, observed by SEM, have the shape of spherical cap. In Ref. [8], we have related the tail of the backscattering gold signal $(1.6 \mathrm{MeV}>\mathrm{E}>1.4 \mathrm{MeV})$ to the characteristics of gold clusters (shape, density, location). Our model shows that clusters of an element A on a substrate B produce the same backscattering spectrum that an homogeneous layer of $\mathrm{B}$ containing a decreasing amount of $\mathrm{A}$. This proportion (instead of being fixed for example by a diffusion coefficient) depends on the shape and the density of clusters. With this model and informations obtained by SEM, it is then possible to fit correctly the gold part of the experimental backscattering spectra and to show that the gold clusters are in fact located at an inner interface. The film resulting from an annealing at $300^{\circ} \mathrm{C}$ is thus successively constituted of a superficial gold layer $(\approx 0.8 \mathrm{~nm})$, a silicide bilayer $\left(\mathrm{Ni}_{2} \mathrm{Si} / \mathrm{NiSi}\right)(\approx 70 \mathrm{~nm})$ and gold precipitates at the silicide/silicon interface or at the $\mathrm{Ni}_{2} \mathrm{Si} / \mathrm{NiSi}$ interface.

After annealing at $450^{\circ} \mathrm{C}$, the two films (with or without gold) are only constituted of NiSi. The gold signal at $1.6 \mathrm{MeV}$ (Figure 1.i) has practically disappeared which indicates a reduction of the number of gold clusters. The SEM image confirms the disappearance of gold clusters. The gold amount in the silicide layer increases from 0.1 to 1 at.\%. which indicates that the gold solubility is probably higher in NiSi than in $\mathrm{Ni}_{2} \mathrm{Si}$. However the main part of gold has been rejected at the free surface of the sample. Annealing at higher temperatures strengthen the gold rejection towards the free surface as shown in the backscattering spectrum of the sample annealed at $600^{\circ} \mathrm{C}$ for one hour (Figure $1 . \mathrm{j}$ ). In these samples, about $80 \%$ of gold is rejected at the surface. The gold concentration in NiSi is uniform and remains about 1 at.\%. 

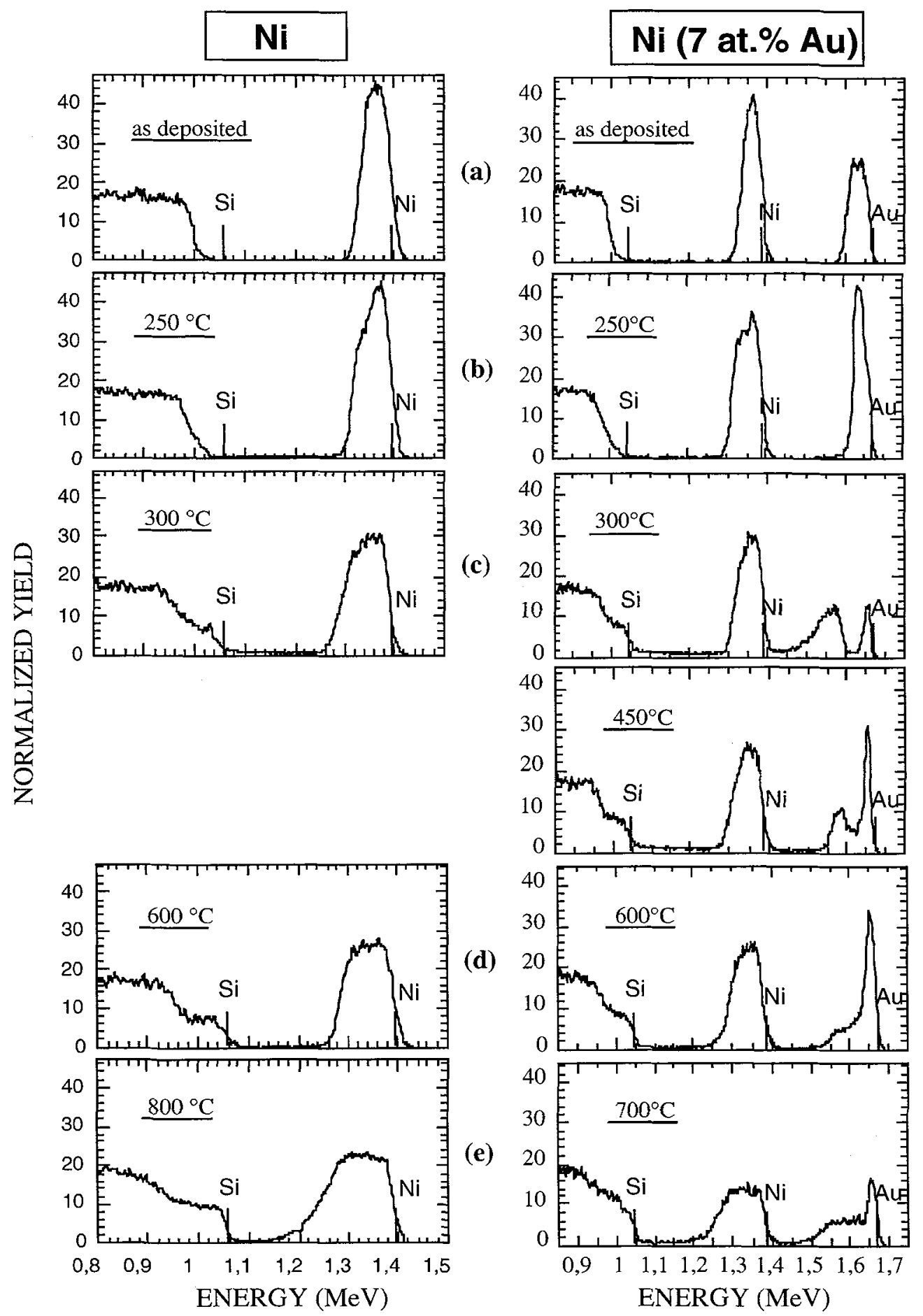

(f)

(g)

(h)

(i) 


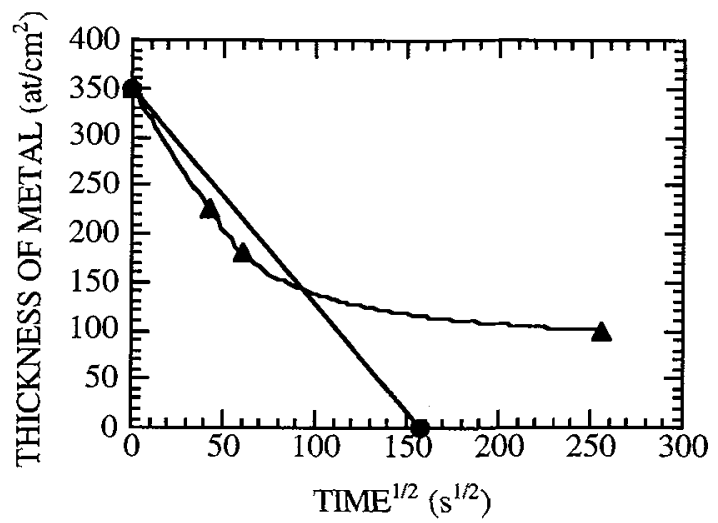

Figure 2: Thickness of unreacted nickel versus the square root of time.

For annealing at temperatures higher or equal to $700^{\circ} \mathrm{C}$ we observed the formation of the $\mathrm{NiSi}_{2}$ phase in the film containing gold (Figure 1.k) whereas $\mathrm{NiSi}_{2}$ is only observed at $800^{\circ} \mathrm{C}$ when a pure nickel film reacts with silicon.

\section{DISCUSSION}

\subsection{Initial stages of silicide formation}

The results obtained for pure nickel agree with the previous studies on nickel silicide formation [9]. The classical scheme of these formation is the following: the orthorhombic structure [10] of $\mathrm{Ni}_{2} \mathrm{Si}$ forms first at temperature above $250^{\circ} \mathrm{C}$. When $\mathrm{Ni}$ is completely transformed in $\mathrm{Ni}_{2} \mathrm{Si}$, $\mathrm{NiSi}$ starts to grow at the $\mathrm{Si} / \mathrm{Ni}_{2} \mathrm{Si}$ interface [11]. These reactions are diffusion controlled and the diffusing species is $\mathrm{Ni}$ [12]. At about $800^{\circ} \mathrm{C}$, the formation of $\mathrm{NiSi}_{2}$ occurs by a nucleation-controlled reaction [13].

The gold presence modify the reaction between the nickel film and silicon. The first stages (annealing at $250^{\circ} \mathrm{C}$ ) of silicide formation in $\mathrm{Ni}(\mathrm{Au})$ films are characterized by an increase of gold concentration at the silicide/nickel interface, the simultaneous presence of $\mathrm{Ni}, \mathrm{Ni}_{2} \mathrm{Si}$ and $\mathrm{NiSi}$, a reduction of the silicide growth rate and the growth of $\mathrm{NiSi}$ by consumption of both $\mathrm{Ni}_{2} \mathrm{Si}$ and $\mathrm{Ni}$. The gold enrichment of the initial $\mathrm{Ni}(\mathrm{Au})$ film during the silicide formation is certainly a consequence of a large difference between gold solubility in nickel silicides and pure nickel [14]. The simultaneous presence of three phases during silicide growth is rarely observed in thin films where phases usually appear sequentially. Two explanations may be given for this simultaneous presence:

- a simultaneous formation of $\mathrm{Ni}_{2} \mathrm{Si}$ and $\mathrm{NiSi}$. In fact, the sequential formation of $\mathrm{Ni}_{2} \mathrm{Si}$ and $\mathrm{NiSi}$ occurs when the thickness of $\mathrm{Ni}_{2} \mathrm{Si}$ is lower than a critical value fixed by the rate of formation of $\mathrm{NiSi}$ (at the $\mathrm{Ni}_{2} \mathrm{Si} / \mathrm{Si}$ interface) and by the transport efficiency in $\mathrm{Ni}_{2} \mathrm{Si}$ [15]. The addition of gold may affect these two parameters and may thus produce a change from sequential to simultaneous formation. This role of impurity on nickel silicide formation has also been mentioned by Ma et al [16] who found that crystalline $\mathrm{Ni}_{2} \mathrm{Si}$ and $\mathrm{NiSi}$ form simultaneously when $\mathrm{Ni}$ reacts with a carbon contaminated amorphous silicon film. A high concentration of oxygen in the metal film may also induce such a change as shown for other silicides (Mn [17], Mo [18], Pt [19], Co [20]).

- the gold enriched layer created at the $\mathrm{Ni}(\mathrm{Au}) / \mathrm{Ni}_{2} \mathrm{Si}$ interface may also act as a diffusion barrier for nickel. The efficiency of this barrier (both its composition and its thickness) increases in time and it is quite reasonable to state that the barrier controls the last stages of silicide formation (when the most significant decrease in the rate of formation is observed).

In fact both phenomenon may happen successively, an unambiguous statement on simultaneous formation would need to analyze in more details the initial stages of silicide formation.

\subsection{Gold redistribution}

As shown on the backscattering signals of gold (Figure 1), the redistribution of gold during the silicide formation can be summarized as follows: at low temperature $\left(250^{\circ} \mathrm{C}\right)$ gold is concentrated in the unreacted $\mathrm{Ni}(\mathrm{Au})$ layer; at $300^{\circ} \mathrm{C}$ gold clusters precipitate at an inner interface $\left(\mathrm{Ni}_{2} \mathrm{Si} / \mathrm{NiSi}\right.$ or $\left.\mathrm{NiSi} / \mathrm{Si}\right)$; at $450^{\circ} \mathrm{C}$ these gold clusters disappear and gold is found at the surface of the silicide layer. The gold enrichment of the 
initial $\mathrm{Ni}(\mathrm{Au})$ film is more likely due to the difference of gold solubility between $\mathrm{Ni}_{2} \mathrm{Si}$ and $\mathrm{Ni}$. The total system $\left(\mathrm{Ni}(\mathrm{Au})\right.$ film / $\mathrm{Ni}_{2} \mathrm{Si} /$ silicon) obtained by annealing at $300^{\circ} \mathrm{C}$ can lower it Gibbs energy by transferring the impurity (Au) at the silicide/Si interface. The difference in interfacial energies appears to be the main driving force of this redistribution since there is no stable gold silicide [3]. At higher temperature $\left(450^{\circ} \mathrm{C}\right)$ gold is mainly found as a uniform layer at the surface of the silicide. The redistribution of gold is thus drastically different below and above the Au-Si eutectic temperature (as was suggested by Hung and Mayer [21]). At temperature in excess of $370^{\circ} \mathrm{C}$, the Au-Si eutectic liquid forms at the silicide/Au interfaces. This leads to a volume increase of the clusters which are thus under compressive stress. The relaxation of this stress is made possible by an upward migration of gold.

The Ni(Au)Si film is stable from $300^{\circ} \mathrm{C}$ to $600^{\circ} \mathrm{C}$. Annealing at $450^{\circ} \mathrm{C}$ for $1 \mathrm{~h}, 600^{\circ} \mathrm{C}$ for $1 \mathrm{~h}$ and $600^{\circ} \mathrm{C}$ for $10 \mathrm{~h}$ indicates that the gold amount dissolved in NiSi is constant and approximately equal to 1 at.\%, a value which can be taken as the solubility limit of Au in NiSi.

\section{3 $\mathrm{NiSi}_{2}$ formation}

In pure nickel films, the formation of $\mathrm{NiSi}_{2}$ is usually observed after annealing at $800^{\circ} \mathrm{C}$. For the $\mathrm{Ni}(7$ at. $\%$ $\mathrm{Au}$ ) film we detected $\mathrm{NiSi}_{2}$ at $700{ }^{\circ} \mathrm{C}$. The formation temperature of $\mathrm{NiSi}_{2}$ is thus lowered in presence of gold. This is in agreement with the fact that the formation of $\mathrm{NiSi}_{2}$ is a "nucleation controlled" reaction[22]. Such reactions are observed when the bulk force driving the reaction ( $\Delta \mathrm{G}$ per unit volume) is weak compare to the opposing force due to the creation of new surfaces $(\Delta \sigma)$ [23]. The addition of gold modify the lattice parameter of $\mathrm{NiSi}_{2}$ and decreases the lattice misfit between $\mathrm{NiSi}_{2}$ and silicon [4], the modification of the nucleation temperature of $\mathrm{NiSi}_{2}$ is thus certainly due to a reduction of the term $(\Delta \sigma)$ associated with interfacial energies. It should however be mentioned that the addition of gold may also change the free energy of the reaction: $\mathrm{Ni}(\mathrm{Au}) \mathrm{Si}+\mathrm{Si} \rightarrow \mathrm{Ni}(\mathrm{Au}) \mathrm{Si}_{2}$.

\section{CONCLUSION}

The solid state reaction between a Ni (7 at.\% Au) thin film and a (111)Si substrate has been studied between $250^{\circ} \mathrm{C}$ and $800^{\circ} \mathrm{C}$. The main features of this reaction are the following:

1 - The three silicides $\left(\mathrm{Ni}_{2} \mathrm{Si}, \mathrm{NiSi}, \mathrm{NiSi}_{2}\right)$ usually observed in nickel/silicon thin film reaction are formed . No "new" silicide (either stable nickel silicides, ternary compounds or metastable gold silicides) appears.

2 - The quantity of gold which can be dissolved in these silicides thin films is limited $\left(0.1\right.$ at. $\%$ in $\mathrm{Ni}_{2} \mathrm{Si}, 1$ at. $\%$ in $\mathrm{NiSi}$ and 2 at. $\%$ in $\mathrm{NiSi}_{2}$ ) .

3 - This limited solubility has however an important effect on silicide formation: the formation of $\mathrm{Ni}_{2} \mathrm{Si}$ and $\mathrm{NiSi}$ usually sequential becomes simultaneous while the temperature of $\mathrm{NiSi}_{2}$ nucleation is decreased by $100^{\circ} \mathrm{C}$ (from 800 to $700^{\circ} \mathrm{C}$ ).

4 - The excess gold (not dissolved in the silicides) precipitate in different forms. At very low temperature $\left(250^{\circ} \mathrm{C}\right)$ the formation of $\mathrm{Ni}_{2} \mathrm{Si}$ and $\mathrm{NiSi}$ induces a gold enrichment of the nickel layer which acts as a diffusion barrier and reduces the silicide kinetic of formation. This enrichment leads to the precipitation of gold clusters at an inner interface $\left(\mathrm{NiSi} / \mathrm{Si}\right.$ or $\left.\mathrm{Ni}_{2} \mathrm{Si} / \mathrm{NiSi}\right)$. These clusters cease to be stable when the silicon-gold eutectic temperature is reached $\left(370^{\circ} \mathrm{C}\right)$.

\section{Acknowledgments}

Discussions with C. Bergman, B. Billia, N. Burle, A. Correia and F. M. d'Heurle and O. Thomas are gratefully acknowledged. The authors are much indebted to C. Dominici, A. Garnier and D. Roux for technical assistance and to J.J and A. Grob for help and advises in RBS simulation.

\section{References}

[1] F. M. d'Heurle, D. D. Anfiteatro, V. R. Deline and T. G. Finstad, Thin Solid Films 128 (1985) 107.

[2] F. Corni, B. Grignaffini Gregorio, G. Ottaviani, G. Queirolo and J. P. Follegot, Appl. Phys. Lett. 73 (1993) 197.

[3] M. Hansen, Constitution of binary alloys (2 $2^{\text {nd }}$ edition, Mc Graw-Hill, New-York, 1958).

[4] J. M. Gay, D. Mangelinck, P. Stocker, B. Pichaud and P. Gas, Procedings of the 4th Int. Conf.

"Surface X-ray and Neutron Scattering" Lake Geneva, USA (1995) to appear in Physica B.

[5] D. Mangelinck, P. Gas, A. Grob, B. Pichaud and O. Thomas, submitted to J. Appl. Phys.

[6] L. R. Doolittle, Nucl. Inst. Meth. B9 (1985) 34.

[7] J. O. Olowafe, M-A. Nicolet and J. W. Mayer, Thin Solid Film. 38 (1976) 143. 
[8] D. Mangelinck, A. Correia, P. Gas, A. Grob and B. Pichaud, J. Appl. Phys. 78 (1995) 1638.

[9] M-A. Nicolet and S. S. Lau, in VLSI Electronics, Microstruture Science, edited by N. G. Einspruch and G. B. Larrabee (Academic, New York, 1983), Vol. 6, p 330.

[10] K. Toman, Acta Crystallogr. 5 (1952) 329.

[11] F. M. d'Heurle, C. S. Petersson, J. E. E. Baglin, S. LaPlaca and C. Y. Wong, J. Appl. Phys. 55 (1984) 4208 .

[12] T. G. Finstad, Phys. Stat. Solidi (a) 63 (1981) 223.

[13] R. Anderson, J. E. Baglin, J. Dempsey, W. Hammer, F. M. d'Heurle, and C. S. Petersson, Appl. Phys. Lett. 35 (1979) 285.

[14] M. Wittmer, C.-Y. Ting, I. Ohdomari and K. N. Tu, J. Appl. Phys. 52 (1981) 6781.

[15] F. M. d'Heurle and P. Gas, J. Mater. Res. 1 (1986) 205.

[16] E. Ma, W. J. Meng, W. L. Johnson and M-A. Nicolet, Appl. Phys. Lett. 53 (1988) 2033.

[17] L. Zhang an D. G. Ivey, J. Mat. Res. 6 (1991) 1518.

[18] F. Nava, S. Valeri, G. Majini, A. Cembali, G. Pignatel and G. Queirolo, J. Appl. Phys. 52 (1981) 6641 .

[19] G. Ottaviani and J. W. Mayer, in: Reliability and Degradation Semiconductor Devices and Circuit,

Eds. M. J. Howes and D. V. Morgan (Wiley, New York, 1981) p. 105.

[20] C. D. Lien and M-A. Nicolet, Mat. Res. Soc. Symp. Proc. 25 (1984) 131.

[21] L. S. Hung, L. R. Zheng and J. W. Mayer, J. Appl. Phys. 54 (1983) 792.

[22] F. M. d'Heurle, S. Petersson, l. Stolt and B. Strizker, J. Appl. Phys. 53 (1982) 5678 .

[23] F. M. d'Heurle, J. Mat. Res. 3 (1988) 167. 